\title{
MSLN wt Allele
}

National Cancer Institute

\section{Source}

National Cancer Institute. MSLN wt Allele. NCI Thesaurus. Code C54329.

Human MSLN wild-type allele is located in the vicinity of $16 p 13.3$ and is approximately 8 $\mathrm{kb}$ in length. This allele, which encodes mesothelin protein, may play a role in the mediation of cellular adhesion. 